\title{
Infrastructure and Institutions: Stakeholder perspectives of stormwater governance in Chicago
}

\section{Introduction}

On September 13, 2008 Chicago experienced a storm event that dropped nearly seven inches of rain on the city in a 24-hour period. The record setting storm event caused massive flooding, resulting in the evacuation of 10,000 homes and \$155 million in damage (Changnon, 2010; Changnon \& Westcott, 2002). More recent storm events have occurred with nearly equal devastation. Storms in April and June of 2013 inundated the city, leading to evacuations, road closures, and the Governor to declare a state of emergency for 44 counties across the State of Illinois. While it is difficult to assign a single storm event to climate change, these record setting storms are indicative of what Chicago is likely to experience on a more frequent basis as a result of climate change (Emanuel, 2014; IPCC, 2014). With annual precipitation projected to increase by as much as $20 \%$, with an increasing fraction of this rainfall occurring in high-intensity events, climate change will have serious implications for flood control and stormwater management in the city (Hayhoe, et al., 2007).

Chicago is not alone in facing these climate change challenges. Cities across the globe, from London to Bangkok, confront urban flooding, drought, and the infrastructural challenges brought by shifts in climate and precipitation patterns (Bulkeley \& Castán Broto, 2012). Using Chicago as a case study, this paper examines how different stakeholder perspectives coalesce around different interventions to address urban stormwater challenges. Urban planners, policy makers, engineers, NGOs, and other stakeholders are developing new institutional and technological strategies to meet the 
dual stormwater and climate change challenge. However, adopting novel urban stormwater governance approaches to address climate change presents a 'wicked' problem imbued with uncertainties and value-conflicts between key stakeholders and decision-makers (Rittel \& Webber, 1973). Without a thorough understanding of the underlying motivations of these stakeholders, the ability of decision-makers to foster more sustainable urban stormwater systems to climate change is limited.

Traditionally, Chicago addressed stormwater through large-scale engineering efforts, typical of grey infrastructure. Initially driven by outbreaks of epidemic diseases, Chicago began developing methods to reduce the flow of polluted water into Lake Michigan, where the city drew its drinking water. Notably, in 1900 the construction of the Chicago Sanitary and Ship Canal reversed the natural flow of the Chicago River. Instead of flowing into Lake Michigan, the Chicago River now flows away from Lake Michigan and into the Des Plaines River, a tributary of the Mississippi River. While this solution resolved some of the pollution problems in Lake Michigan, it did little to reduce the load of sewer systems during rain events, which easily inundate and produce combined sewer overflows (CSOs). In order to provide a floodwater outlet and reduce the load of the sewer systems during rain events the Metropolitan Water Reclamation District of Greater Chicago (MWRD) began constructing the Tunnel and Reservoir Plan (TARP) in 1972. The TARP is designed to capture, convey, and store combined sewage during storms through a series of deep rock tunnels and surface reservoirs, which later channel this water towards treatment plants when capacity becomes available (Malec, 2003). Although construction launched in 1975, many factors have delayed completion until 2029. 
Urbanization also brings an increase in hard or impervious surfaces. By some estimates these surfaces can comprise as much as $67 \%$ of the urban land area (Gartland, 2008; Matthews, et al., 2015). This human alteration to the hydrology of the urban environment, along with climate change, is likely to exacerbate many of the stormwater challenges Chicago already faces, such as CSOs and flooding. CSOs occur when the volume of water entering exceeds the capacity of the sewage treatment plant. This is a significant concern given that storm events producing as little as .67 inches of rain in 24 hours can overwhelm the existing stormwater infrastructure and result in CSOs that dump a mixture of untreated sewage and stormwater runoff into the Chicago River and Lake Michigan (Dorfman \& Mehta, 2011). CSOs are a considerable problem in Chicago with 2,036 discharge events occurring in 2009 alone (NRDC, 2010). In Chicago, the increased magnitude of flooding and CSO events can be attributed to alterations of land-surface wrought by urbanization and the history of stormwater management policy (Ntelekos, et al., 2010).

Chicago is also working to comply with National Pollutant Discharge Elimination System (NPDES) Phase II requirements. NPDES is a permitting program administered under the Federal Clean Water Act (CWA). While the initial focus of the program was to reduce industrial point sources of pollution, efforts have expanded to bear upon stormwater pollution, attempting to manage it at discharge points, typically sewer outfalls (White \& Boswell, 2007). Phase II of the CWA requires public education and outreach, public involvement, illicit discharge detection and elimination, construction site runoff control, post construction runoff control, and pollution prevention as 'minimum control measures' (EPA, 2005). In Chicago, the MWRD is in charge of treating the city's sewage 
and stormwater runoff at seven treatment facilities and maintaining compliance with NPDES Phase II requirements. Efforts have focused primarily on stormwater control areas, such as areas relying on separate storm sewers and riparian areas that allow stormwater to flow directly into water bodies (Powers \& Emanuel, 2014).

Chicago has been successful at implementing both structural and non-structural best management practices (BMPs) to treat stormwater runoff. Non-structural BMPs utilize ordinances and education initiatives to improve water quality while structural BMPs entail physical changes to infrastructure or the landscape to reduce the impact of stormwater runoff, such as dry basins, wetlands, filter strips and other forms of green infrastructure (Kaplowitz \& Lupi, 2012). Chicago has been able to utilize green infrastructure's broad appeal to implement a number of projects and programs capable of enhancing water quality in the city, such as the Stormwater Ordinance, the Green Roof Initiative, and the Green Alleys Program. These investments in stormwater management are popular among decision-makers and technocrats due to their ability to garner multiple benefits, increase the city's resilience to extreme rain events and climate change, and reduce the burden of stormwater flows on the sewer system (Emanuel, 2014).

Not all stormwater BMPs and forms of green infrastructure, however, are capable of adequately addressing the range of pollutants or hazards inherent to a particular watershed; they also vary considerably in cost and expertise to implement and maintain (Kaplowitz \& Lupi, 2012). Moving forward, decision-makers must choose how resources are allocated for stormwater management and decide among the options available to reduce the impact of stormwater at different sites across the city. 
One of the constraints decision-makers and planners face is generating the funds to build green infrastructure. In Chicago, stormwater is the only major infrastructure system not paid for through user fees. Instead, stormwater infrastructure funding comes from general revenue. While many cities pay for stormwater infrastructure through general funds, the number of stormwater utilities operating in the United States is quickly rising. Nearly 1,600 stormwater utilities now function in the United States, with 22 operating in Illinois (Campbell, Dymond, \& Dritschel, 2016). Cities, such as Philadelphia for example, have been able to implement parcel-based stormwater fees that charge property owners a fee based on the amount of impervious cover on their property and provide a credit structure that incentivizes stormwater retrofits (Fitzgerald \& Laufer, 2016).

Decision-makers are also faced with gaps surrounding the costs and benefits to manage stormwater through green infrastructure, including maintenance costs, and how the cumulative effects of many small-scale, decentralized and distributed projects across the city will impact stormwater flows (Emanuel, 2014). Despite these unknowns and constraints, many government and non-government actors within the city are looking towards replacing some of Chicago's impervious surfaces with porous pavement, bioswales, rain gardens, and other forms of green infrastructure to lessen the pressure on the stormwater treatment facilities and reduce the number of CSOs (Dorfman \& Mehta, 2011). With limited resources and diverging views on the efficacy of green infrastructure, however, there is an inherent conflict about what stormwater is, how resources are allocated to manage it, and the best way to do so. 
Various approaches have been used to understand the perspectives and preferences of those involved in urban environmental governance and decision-making. Kaplowitz and Lupi (2012), for example, used a choice experiment to reveal stakeholder preferences for BMPs to address stormwater. Their results found that stakeholders hold clear preferences for some types BMPs over others. Homeowner's, for example, were found to prefer management plans with high levels of streambank naturalization in their alternative management plans. Similarly, Byrne et al. (2015) surveyed green-space users to understand how their knowledge about climate change and adaptive responses shapes their attitudes towards green infrastructure as an adaptive response to climate change. The findings suggest that green-space users favor tree planting if they perceive climate change to be economically disruptive. Dobbie and Green (2013) also surveyed public perceptions of wetlands to understand the different landscape characteristics that guide the way people see and interpret the environment. Relatedly, Matthews et al. (2015) used a combination of interviews and literature review to identify the barriers and drivers of adopting green infrastructure. While these studies have proven useful for revealing how various stakeholders understand and perceive the environment, little work has sought to clarify how these perceptions relate to one another, interact, and potentially conflict.

This article addresses this gap by exploring how stakeholders embedded within different departments, agencies, organizations, and structures of urban stormwater governance adhere to different discourses of stormwater governance. Understanding such differences is important not only in terms of fostering cooperative planning across city departments, but also across the spectrum of government and non-government actors concerned with the implementation of more sustainable forms of urban water 
management. Arriving at a particular solution, however, is difficult due to the 'siloed' and fragmented nature of urban environmental governance (Bulkeley, 2010; Cousins, 2016; Fitzgerald \& Laufer, 2016) and the complexity of urban social-ecological systems (Ernstson et al., 2010; Forrester, Cook, Bracken, Cinderby, \& Donaldson, 2015; Schäffler $\&$ Swilling, 2013). This presents a difficult governance problem with a range of plausible approaches and perspectives on the best means to mitigate and adapt to environmental challenges (Dryzek, 1997; Rittel \& Webber, 1973). With a greater emphasis on broad stakeholder participation in urban environmental governance and decision-making, accommodating and moderating multiple and competing perspectives will become a greater part of urban green-space planning.

The aim is to reveal the shared framings of stormwater governance that exist among the different actors situated within different 'silos' of urban water management. Through Q-methodology, this article reveals two dominant perspectives of stormwater governance that cut across various silos of water management in Chicago. The first, strongly views the combination of stricter regulations and data-driven approaches as the best system to improve stormwater management in Chicago. The second desires more integrated management approaches and more robust economic instruments capable of assigning a monetary value to stormwater as critical to resolving problems related to stormwater. Understanding how these two social perspectives may enable and constrain solutions through their interaction is important for guiding more sustainable strategies aimed at resolving the multiple challenges Chicago faces.

\section{Methods}


This study uses Q-methodology to examine and compare multiple perceptions and understandings of stormwater management approaches in Chicago. Q-methodology works by revealing different social perspectives, attitudes, or understandings about a topic in a structured and statistically interpretable form (Robbins and Krueger 2000; Watts and Stenner 2012; Eden, et al. 2005). Instead of measuring how particular views are distributed across the population and relate to demographic or other variables, as in traditional survey research, Q-methodology uses an inverted factor analysis to reveal the patterns in the ways people structure their world-views (Webler, Danielson, \& Tuler, 2009). This is the inverse of more traditional survey approaches, where individuals are correlated rather than variables (Danielson, Webler, \& Tuler, 2009; O’Neill, Boykoff, Niemeyer, \& Day, 2013). In other words, the goal of Q-methodology is to identify the viewpoints that exist, not to determine the distribution of viewpoints across a population. The approach allows the researcher to identify shared discourses and competing framings about a policy relevant topic or contentious issue.

Q-methodology follows a number of well-established guidelines that include: 1) identification of a discourse, or domain of subjectivity; 2) collection of statements and creation of the concourse, 3) development of the Q-set, also known as the Q-sample, 4) participant selection (P-set); 5) Q-sorting exercise; 6) statistical analysis; and 7) interpretation (Robbins \& Krueger, 2000; Swedeen, 2006; Watts \& Stenner, 2012; Webler et al., 2009). Following these guidelines, this research proceeded in three primary phases.

During the initial phase, environmental and planning organizations, as well different government agencies and departments, were identified and selected to represent 
the possible range and diversity of different agencies and organizations involved in debates over stormwater governance and management in Chicago. Archival research was then conducted on each of these organizations, and informal semi-structured interviews were conducted with leaders and representatives of these groups. Typical of Qmethodology, interview subjects were purposively selected to be representative of the range of government and non-government viewpoints on stormwater management in Chicago and the region. In total, 13 different actors were interviewed in Chicago, including leaders from six different environmental or planning NGOs and seven leaders or representatives from city, state, and federal agencies and departments, such as the Chicago Department of Water, Chicago Department of Transportation, MWRD, Illinois Department of Natural Resources, and the United States EPA. During the interviews, questions focused on asking individuals about their role in stormwater governance, perceived barriers and opportunities in stormwater management, perspectives and preferences of current strategies available, and how they think stormwater should be managed in the future.

A comprehensive list, or concourse, of statements containing all relevant discourses pertaining to recommendations of how stormwater should be managed and governed was then constructed verbatim from the interviews, as well as from academic articles, newspapers, policy documents, and NGO publications. This strategy focused statement collection around what Watts and Stenner (2012, p. 55) term 'conduct questions', or those statements that address how responses or actions should proceed in relation to a subject matter, such as stormwater. Statement collection continued up to a 'saturation point', where inclusion of additional statements no longer increased the 
breadth and diversity of statements (Eden et al., 2005; Glaser \& Strauss, 1967). At this point, the 376 collected statements were refined for clarity, sorted thematically, and coded into four domains_-goals, barriers, preferred management approaches, and perspectives of current strategies. The final concourse, or Q-set, consisted of 40 representative statements, which aligns with recommendations in the literature (Webler et al., 2009).

During the second phase, 15 participants were selected to carry out the Q-sorts. In contrast to typical surveys, Q-methodology relies on small non-random sample sizes. The goal of using a small strategic sample size, instead of a large randomized sample, is to ensure "comprehensiveness and diversity, rather than representativeness or quantity" (Eden et al., 2005, p. 417). Based on this general guideline, the Chicago participants were purposively chosen to establish representation from all types of stakeholder groups and to ensure the widest range of perspectives in relation to stormwater governance in Chicago (Brannstrom, et al., 2011; Brannstrom, 2011; Fisher \& Brown, 2009; Robbins, 2006). Specifically, participant selection occurred on the basis that they offer a unique and wellinformed perspective that contributes to ongoing debates and initiatives about how stormwater governance should proceed in Chicago and the region. This was based on their active role and affiliation with predominant environmental or planning NGOs or with city, state, or federal departments or agencies involved in directing changes in stormwater governance in Chicago. Eligibility for participation in the Chicago study was thus based on one's structural position (e.g. a department head), their participation in stormwater planning or governance processes, and in establishing representation of all types of stakeholder groups. Overall, the organizational background of the participants 
included government departments and agencies focused on policy and management (national, state, regional, and city; eight participants) and non-governmental planning and environmental organization (seven participants).

Once the invited participants agreed to take the study they were presented with a grid organized in a quasi-normal distribution and asked to sort statements along a scale from +3 (most agree) to -3 (most disagree) (Table 1). This forces respondents to reflect on the placement of each statement and make priorities in how they rank the statements.

\section{[Table 1 here]}

In the third phase, the Q-sorts were analyzed with PQMethod software to identify common orderings of statements and indicate shared points of view and subject positions. Factor analysis works by mathematically creating new variables, or factors, that explain variation among many variables (the Q-sorts). This study used centroid analysis in order to find common patterns among the different Q-sorts. While there are no set rules on how many factors to extract, this study used the Kaiser-Guttman criterion to identify the number of extracted factors. The Kaiser-Guttman criterion posits that factors should only be retained if they have an eigenvalue (EV) of 1.00 or above-factors with an EV of less than one account for less variance than a single Q-sort (Guttman, 1954; Kaiser, 1960; Watts \& Stenner, 2012). Using the Kaiser-Guttman criterion, two factors were retained and extracted for analysis. The factors were then rotated using varimax rotation. This common procedure in Q-methodology produces a factor solution that maximizes the amount of explained variance and the number of individuals associated with only one factor (Setiawan \& Cuppen, 2013; Webler et al., 2009). The result produces an idealized sort for each factor, which is meant to represent a distinct social perspective or 
knowledge group (Barry \& Proops, 1999). These ideal types were then interpreted and refined based on follow-up interviews and comments provided at the end of the Q-sort, which asked each respondent to explain the statements they most agreed and disagreed with and why.

While Q-methodology is recognized as a robust method for capturing different discourses and idealized accounts about a topic, there are a number of limitations to the method and approach taken in this study. One of the primary limitations of Qmethodology is that it does not warrant generalizations about how widely held the revealed perspectives or discourses are in a population (Webler et al., 2009). This is because Q-methodology tests statements, not people. The perspectives identified from a Q-methodology study, however, can inform a representative large-n survey to draw generalizations about how widely held a perspective is. The Chicago case, presented here, is also limited by the non-random sample that is not representative of the perspectives held by 'non-experts' and the general public.

\section{Results}

The factor analysis revealed two factors or knowledge groups that make up the dominant perspectives of those involved in stormwater management. The first, the Infrastructural Interventionist (F1), sees stricter laws and improved science as necessary to rework urban stormwater infrastructure. The second, the Institutional Interventionist (F2), perceives the development of new institutions to foster integrated water resources management and economic instruments to put a value on stormwater as necessary to address stormwater problems. Combined, the two factors explain $42 \%$ of the variance (Table 2). Respondent's perspectives and preferences towards stormwater management come 
together around developing integrated approaches that are capable of utilizing market, economic, or financial principles. Disagreement in stakeholder preferences and perspectives revolve around the role of infrastructure and how it is developed and implemented. Specifically, social perspectives diverge over the role of large centralized infrastructural systems, or grey infrastructure, in mitigating stormwater. This section provides an overview of each factor. Appendix A shows an idealized sorting pattern for each group across all the statements.

[Table 2 here]

\subsection{Factor One: Infrastructural Interventionist}

The Infrastructural Interventionist supports stricter laws and regulations in tandem with data-driven approaches as the primary means to achieve improved stormwater management (\#9: +3; \#11: +3). Respondents, who loaded onto this factor, or knowledge group, include a diverse set of governmental and non-governmental actors. In total seven people loaded onto this knowledge group. One is a federal official and three others represent municipal officials - a water engineer, a city planner, and a city parks official. The remaining three represent officials from prominent NGOs in Chicago. Table 3 indicates the distinguishing statements that define this group.

[Table 3 here]

Beyond implementing data-driven approaches and advocating for stricter laws and regulations to manage stormwater, a shared sentiment among Infrastructural Interventionists is to apply economic principles to stormwater management. Actors strongly agree that economic instruments are needed to put a value on stormwater in order to treat it a resource rather than a hazard $(\# 14:+2)$. This is reflected in their support 
for mitigation banks to foster public-private partnerships that allow developers to meet LID requirements by paying into a bank (\#16: +2). In addition to developing economic instruments to manage stormwater, actors are in favor of developing stormwater fees and cost sharing plans for municipalities (\#21: +2$)$.

When it comes to infrastructure, many see large grey infrastructural developments as key ways to mitigate the impacts of stormwater and flooding depending on how that water is utilized $(\# 28:+2)$. The sentiment among Infrastructural Interventionists is that large centralized projects, referred to as grey infrastructure, can foster beneficial uses of stormwater as long as the systems are not overwhelmed. This is one reason why many of the respondents in this group see a cultural problem with the way engineers develop solutions to stormwater management that neglect the role of green infrastructure $(\# 7:+1)$. A largely shared opinion among those in this group is that the data exists for the adoption of green infrastructure and to quantify its performance (\#3: -2), but many of the institutional and cultural barriers to implementing green infrastructure need to be overcome. This partially explains the relative ambivalence, or lack of agreement or disagreement, towards a preferred approach, whether centralized (grey) or distributed (green). For example, this group neither agrees nor disagrees with the statement that centralized urban water systems are maladapted to address climate change impacts and environmental stressors (\#29: 0), or resilience of urban water systems will be improved by moving away from the centralized model and using more distributed solutions like green infrastructure (\#32: 0). Stormwater management, for this group, is primarily about getting the proper mix of infrastructural solutions, as well as government actions and market mechanisms, to manage stormwater, and then applying scientific principles to 
direct where to make interventions in the system. Receiving input from corporations or private interests would only hamper this process (\#15: -3).

Stormwater fees are also perceived as a feasible approach for long-term and successful stormwater management rather than being problematic (\#22: -2$)$. This is mirrored in the shared sentiment among many of the actors in their disagreement that it is hard to justify money for stormwater management due to it potentially taking away funds from other services such as recreation or emergency management. Stormwater fees are perceived as an important step towards setting up specific funds for stormwater management, which may in turn provide other services such as recreation or more green space. This is one reason why many of the actors see spending on stormwater as justifiable in the long-term.

Interestingly this group disagrees with the idea that cities are too congested and built up for many types of green infrastructure (\#4: -1). A commonly held perspective is that roads and rooftops represent a significant amount of space to implement green infrastructure, but when designing larger catchment areas, space may become a hurdle to green infrastructure. Respondents in this group also tended to disagree that implementing green infrastructure and developing green initiatives within the city has the ability to alter the socio-economic dynamics of neighborhoods and lead to green gentrification (\#34: -2).

\subsection{Factor Two: Institutional Interventionist}

The Institutional Interventionist perceives integrated management approaches as well as developing economic instruments to put a value on stormwater as critical to resolving problems related to stormwater $(\# 20:+3 ; \# 14:+3)$. In total, six respondents loaded onto 
this factor or group. One works for a prominent national environmental organization, another works for the State government, two work for local environmental NGOs, another works for the Cook County, and the remaining respondent works for the Metropolitan Water Reclamation District of Greater Chicago. Table 4 provides an overview of statements associated with this group.

\section{[Table 4 here]}

In addition to implementing integrated approaches and placing a value on stormwater, this group prefers for more distributed projects. They agree that urban resiliency is likely to increase by moving away from a centralized model and adopting alternative solutions like green infrastructure $(\# 32:+2)$. This is reflected in their disagreement with the statement that distributed projects are not effective, do not scale up, and will not meet the level of stormwater abatement needed (\#33: -2). Similarly, this group disagrees with the perspective that larger centralized facilities are more costeffective and make more financial sense than distributed and decentralized projects (\#30: -2). While sufficient urban space to implement green infrastructure is perceived as a limitation $(\# 4:+1)$, they see retrofits on the existing built environment, in tandem with newly installed green infrastructure, as a means to overcome some of these limitations (\#40: +2).

A common position among the actors is that these decisions should be data driven and fact based (\#11: +2$)$, but improved science and data will not be sufficient to garner significant change. Instead, the data-driven approaches need to be linked with improved, and possibly new, institutions and rules to manage stormwater $(\# 37:+2)$. Like the Infrastructural Interventionist, the Institutional Interventionist disagrees that one of the 
biggest challenges is increased regulation (\#1: -2$)$ and that it is hard to justify money for stormwater management (\#35: -3). What sets this perspective apart, however, is their sentiment towards creating institutions and rules that foster integrated approaches. This will lead to garnering multiple benefits and reduced costs, as one respondent noted in a post-sort interview, because "integration leads to synergistic design which saves money, provides greatest benefits, and meets the needs of the community." The respondent goes on to note that it is becoming easier to justify money for stormwater management due to an increased awareness among people "that there are other benefits besides just managing stormwater that they can get from their investments" (Respondent 4).

\section{Points of Agreement}

Actors' perspectives and preferences towards stormwater management tend to converge around developing approaches that are integrated and capable of utilizing market, economic, or financial principles (\#20: $+2,+3)$. Additionally, it is a commonly shared perspective across both factors that both market forces and increased regulation are necessary for effective stormwater management, which explains why respondents tend to disagree that one of the biggest barriers is increased regulation (\#1: -2). This is important as it provides a common foundation that both perspectives can draw from and potentially come to an agreement on. As one respondent explains, "existing regulations are clearly not enough to effectively manage stormwater. While improvements to local codes and ordinances are needed, this has to be part of an integrated approach to maximize benefits and efficiently manage water as a resource" (Respondent 1). 
As means to foster integrations, both factors lean towards developing economic instruments capable of placing a value on stormwater (\#14: $+2,+3$; \#17: -1, -1). Respondents tended to favorably view the development of a tradable credit system to encourage investment in green infrastructure at the lowest possible cost $(\# 12:+1,+1)$. Part of this is driven by a vision of sustainability that reflects a balance among the three pillars of sustainability - the economy, the environment, and equity. As one stormwater professional lamented, "If there is an economic driver people respond to that. All too often we are only driven by that and nothing else, but slowly we're moving to recognize that sustainability is a three legged stool and economics is just one of those legs and the others should get equal weight" (Respondent 2). Scientific and data driven approaches, however, should guide decisions capable of balancing all aspects of sustainability (\#11: $+3,+2)$.

Both groups strongly disagree that every dollar spent on a water quality project represents fewer dollars for emergency services, recreation, or funds for other services (\#35: -3, -3). As one respondent explains:

Water quality projects, and the money to pay for them, can help reduce the need for emergency services by improving flood prevention and mitigation. They can also improve recreational opportunities, create jobs, and provide many other benefits. It's easy to justify money for stormwater management because insufficient management of stormwater is extremely costly. (Respondent 1)

As another respondent goes on to note, citing New York and Philadelphia as examples,

They did a triple bottom line analysis that showed that for every dollar they invest in green infrastructure, they're going to see two dollars in benefits. That's everything from reduced urban heat island effect, improved stormwater controls, reduced mortality, reduced absenteeism, [and] improved school performance. (Respondent 7) 
In addition, actors view green infrastructure or LID as the approach that offers the most economic benefits by deferring investments in large grey infrastructure projects, or by replacing it entirely $(\# 31:+1,+1)$.

Actors also tended to disagree that stormwater fees are problematic and not a feasible approach to achieve long-term success (\#22: -2, -2). As one respondent noted,

Municipalities need fees and cost sharing plans. Development needs to be ultimately responsible for its own actions and displacement of water, whether you are a mega church with a sea of parking, or a road, it will happen when cities stop taking responsibility for everyone's hair-brained development schemes. (Respondent 3)

In Chicago, stormwater is the only major infrastructure system that is not typically paid for through user fees. For many of the respondents the failure to implement fees for stormwater is the fault of many of the political leaders in Chicago who may not be knowledgeable about stormwater issues or have the incentives to innovate $(\# 10:+1,+1)$.

While respondents in both groups were inclined to agree that political leaders needed to be more informed and that fees and economic measures need to be utilized, they tended to be ambivalent towards community driven interventions aimed at homeowners (\#26: 0, +1). Similarly, actors often remained neutral over questions aimed at the capacity of NGOs to better address stormwater issues and implement green infrastructure (\#39: 0, -2). As one water resource manager noted, "NGOs are never going to be able to change the handling of stormwater - this is a jurisdictional issue in Illinois, where we have given every small municipality the ability to do whatever they want" (Respondent 3). The respondent was clearly talking about the role of NGOs more broadly across the state of Illinois, but saw a role for NGOs to collaborate with and conduct outreach with decision-makers at the city, state, and federal level. This also helps explain 
the indifference among many of the respondents in directing outreach and education at the household and community level—because it is believed that efforts should be directed at government officials with the decision-making capacity to implement changes.

\section{Points of Disagreement}

The results indicate important points of difference between factors. Conflicting points of perspective primarily center on infrastructure and its development, maintenance, and implementation. In particular, social perspectives diverge over the role of large infrastructural systems in stormwater mitigation and its role for water quality and supply (\#28: +2,-1). This presents the biggest point of disagreement between both groups and is partially reflected in the perception that a cultural problem exists, where engineers only see engineering solutions $(\# 7:+1,-1)$. As one respondent noted in regards to green infrastructure, "It's a way to address climate change... And green infrastructure performance improves over time versus grey infrastructure, which tends to decline over time. So I just think it's a better investment. Not that it can replace grey infrastructure, but it has to be an integrated approach." The respondent goes on to explain, however, that in terms of implementation "I don't think there's really an awareness [among engineers] about green infrastructure. I think they talk about it, because they feel they have to, not because they really believe in it" (Respondent 7). This presents a barrier, as another respondent noted, because “I don't see a lot of collaboration between and among infrastructure groups. We do have an office... It's mostly a scheduling office though. It's coordination but not collaboration" (Respondent 11). 
Further examining the statements showing the most variance in scores, what is revealing is not a set of polarizing visions, but one factor strongly holding a position while the other factor maintains a more neutral position. The Institutional Interventionist, for example, strongly holds that the resilience of urban water systems will be improved by moving away from the centralized infrastructure model and by embracing green infrastructure, but the Infrastructural Interventionist remains neutral on this point (32: 0, +2). Similarly, the Institutional Interventionist more strongly shows a need to focus on existing development while the Infrastructural Interventionist remains more noncommittal to this approach $(40: 0,+2)$. The same also holds for perspectives related to the need for new institutions and rules, with the Institutional Interventionist favoring this perspective while the Infrastructural Interventionist remains noncommittal $(37: 0,+2)$.

Moreover, it is important to distinguish the points the Infrastructural Interventionist agrees with but the Institutional Interventionist views more neutrally. Two statements, in particular, stand out. The first is the creation of mitigation banking for stormwater management $(\# 16:+2,0)$. This divide stems from the different ways mitigation banking is perceived, either as enabling market participants to develop the most cost-effective means for mitigating stormwater or as enabling some actors to avoid implementing on-site mitigation measures. These concerns stem from respondents' experience and knowledge of wetland mitigation banking schemes in the Chicago region and the issue of commensurability (cf. Robertson, 2004). As one respondent explains,

The problem I have [with mitigation banking schemes] is if your development is here... and you want to capture it there... You're capturing stormwater from somewhere else and this development isn't really doing much. First, you're kind of perpetuating the problem because now this development is going in without a [stormwater] control. Second, I don't know if the water quality benefit you're getting from here is the same as from over there. (Respondent 6) 
The second is on the development of stricter laws and regulations to address stormwater (\#9: $+3,0)$. While the Infrastructural Interventionist strongly holds that there is a need for stricter laws and regulations, the Institutional Interventionist views this statement with less confidence. The difference of perspective is likely more attributable to the Institutional Interventionist desiring better enforcement and more integration among the institutions involved in stormwater management. As one respondent explains, many of the rules and regulations are in place, "but the biggest challenge is just getting it integrated into standard practice... If you had that... you could pull all these groups [within the city] together and you could really tackle [stormwater] problems more strategically than we are currently doing” (Respondent 7).

Finally, it is also worth noting the areas of disagreement where one factor interpreted a statement negatively whereas the other factor perceived the statement neutrally. Two statements, in particular, stand out. The first centers on the role of private interests in developing stormwater controls. The Infrastructural Interventionist strongly disagrees with the statement that corporations and private interests should have a chance to participate in forming stormwater abatement targets; however the Institutional Interventionist is more impartial to the statement (\#15: $-3,0)$. The impartiality presented by Institutional Interventionists should not be read as an ambivalence towards private actors participating in the development of targets they need to be held accountable for, but instead as a preference for market-oriented approaches that involve the private sector. The second focuses on the perceived financial advantage centralized stormwater projects may offer. The Institutional Interventionist disagrees with the assertion that centralized (grey) stormwater projects make more financial sense than distributed and decentralized 
(green) stormwater projects, but the Infrastructural Interventionist maintains more unattached positions. The differences reflected in these two statements signal one of most confrontational points that may present barriers to further improving stormwater management. The statements reflect differences in perceptions of financing infrastructure to meet stormwater abatement targets and the type of infrastructure to put in place, which remains a contentious issue-one that may impede inter-stakeholder cooperation.

\section{Conclusion}

As urban environmental governance and decision-making comes to embrace the participation of a wider range of professions and stakeholders, understanding how multiple perspectives are connected and disconnected to each other is important for shaping more sustainable urban landscape transitions. Using Q-methodology, this article examined the ways stakeholder preferences and perspectives of stormwater governance converge and diverge over the preferred strategies to address stormwater challenges in Chicago. The analysis revealed two salient perspectives on stormwater governance: the Infrastructural Interventionist and the Institutional Interventionist. The Infrastructural Interventionist prefers stricter laws and regulations, coupled with more scientific and data-driven approaches, as the best route towards achieving more sustainable forms of urban stormwater infrastructure and management. The Institutional Interventionist perceives new institutions and rules to foster integrated management approaches, as well as economic instruments capable of assigning a value to stormwater, as critical to resolving stormwater problems. Conflicting points of perspective arise around the 
preferred type of infrastructure (grey v. green) to deal with stormwater and its development and implementation.

While the results of the study suggest that differences may not be irreconcilable in coordinating more sustainable efforts, the contrasting viewpoints may impede more truly collaborative engagements. The findings support research that has found competing values and the fiscal impacts of governing stormwater infrastructure as divisive issues (Fitzgerald \& Laufer, 2016) and that collaboration remains situated within the possibilities afforded by engineering science in technocratic settings (Cousins, 2016; Finewood, 2016). This suggests that the different infrastructural and institutional viewpoints revealed in this study may be more broadly held. Rather than basing these differences on departmental or organizational affiliation, however, this analysis drew on Q-methodology to reveal the discursive alliances and divisions that forge disparate groups together. The lack of consensus on the development, maintenance, and implementation of infrastructure may present challenges for integrated governance approaches for many cities, but empirically rendering these differences visible allows stakeholders to engage more constructively.

With many cities across the globe facing similar challenges, further research into how grey and green approaches complement each other may help resolve some of the differences in stakeholder opinion. Scholars suggest that boundary organizations (Freitag, 2014; Kirchhoff, Lemos, \& Engle, 2013; Ward, 2013) and experimentation (Castán Broto \& Bulkeley, 2013; Farrelly \& Brown, 2011; Fitzgerald \& Laufer, 2016) offer a means to transform environmental governance in more sustainable pathways by fostering organizational learning and collaboration among and between groups (Brown, 2008; 
Newell \& Cousins, 2015; Pallett \& Chilvers, 2014; Star \& Griesemer, 1989). The lesson from this case, however, is that departmental silos may not adequately explain variation in stakeholder perspectives. Instead, the findings show that connections forge across diverse stakeholder groups through shared ways of constructing solutions to a problem, and as such, enable and constrain technical and institutional interventions. In planning environments where local officials support many of the same broad goals of developing more sustainable cities, but may disagree on the means to achieve them, Q-methodology provides a tool to identify areas of conceptual agreement and disagreement that can inform policy that is more agreeable to all actors involved. 


\section{References}

Barry, J., \& Proops, J. (1999). Seeking sustainability discourses with Q methodology. Ecological Economics, 28(3), 337-345.

Brannstrom, C. (2011). A Q-Method Analysis of Environmental Governance Discourses in Brazil's Northeastern Soy Frontier. The Professional Geographer, 63(4), 531549.

Brannstrom, C., Jepson, W., \& Persons, N. (2011). Social Perspectives on Wind-Power Development in West Texas. Annals of the Association of American Geographers, 101(4), 839-851.

Brown, R. R. (2008). Local institutional development and organizational change for advancing sustainable urban water futures. Environmental Management, 41(2), 22133. https://doi.org/10.1007/s00267-007-9046-6

Bulkeley, H. (2010). Cities and the Governing of Climate Change. Annual Review of Environment and Resources, 35(1), 229-253.

Bulkeley, H., \& Castán Broto, V. (2012). Government by experiment? Global cities and the governing of climate change. Transactions of the Institute of British Geographers, 38(3), 1-15. https://doi.org/10.1111/j.1475-5661.2012.00535.x

Byrne, J. A., Lo, A. Y., \& Jianjun, Y. (2015). Residents' understanding of the role of green infrastructure for climate change adaptation in Hangzhou, China. Landscape and Urban Planning, 138, 132-143.

https://doi.org/10.1016/j.landurbplan.2015.02.013

Campbell, C. W., Dymond, R. L., \& Dritschel, A. (2016). Western Kentucky University Stormwater Utility Survey 2016, 1-50. Retrieved from http://www.wku.edu/engineering/civil/fpm/swusurvey/western_kentucky_university _sw\%5Cnu_survey_2014.pdf

Castán Broto, V., \& Bulkeley, H. (2013). A survey of urban climate change experiments in 100 cities. Global Environmental Change: Human and Policy Dimensions, 23(1), 92-102. https://doi.org/10.1016/j.gloenvcha.2012.07.005

Changnon, S. A. (2010). Stormwater Management for a Record Rainstorm at Chicago. Journal of Contemporary Water Research \& Education, 146(1), 103-109.

Changnon, S. A., \& Westcott, N. E. (2002). Heavy Rainstorms in Chicago: Increasing frequency, altered impacts, and future implications. Journal of the American Water Resources Association, 38(5), 1467-1475. https://doi.org/10.1111/j.17521688.2002.tb04359.x

Cousins, J. J. (2016). Volume control: Stormwater and the politics of urban metabolism. Geoforum. https://doi.org/10.1016/j.geoforum.2016.09.020

Danielson, S., Webler, T., \& Tuler, S. P. (2009). Using Q Method for the Formative Evaluation of Public Participation Processes. Society \& Natural Resources, 23(1), 92-96. https://doi.org/10.1080/08941920802438626

Dobbie, M., \& Green, R. (2013). Public perceptions of freshwater wetlands in Victoria, Australia. Landscape and Urban Planning, 110, 143-154. 
https://doi.org/10.1016/j.landurbplan.2012.11.003

Dorfman, M., \& Mehta, M. (2011). Chicago, Illinois. In Thirsty for Answers: Preparing for the Water-Related Impacts of Climate Change in American Cities. Natural Resources Defense Council.

Dryzek, J. S. (1997). The Politics of the Earth: Environmental Discourses. New York: Oxford University Press.

Eden, S., Donaldson, A., \& Walker, G. (2005). Structuring subjectivities? Using Q methodology in human geography. Area, 37(4), 413-422. https://doi.org/10.1111/j.1475-4762.2005.00641.x

Emanuel, R. (2014). City of Chicago Green Stormwater Infrastructure Strategy. Chicago.

EPA. (2005). Stormwater Phase II Final Rule: Small MS4 Stormwater Program Overview, 1-3. Retrieved from http://www.epa.gov/npdes/pubs/fact1-0.pdf

Ernstson, H., Leeuw, S. E., Redman, C. L., Meffert, D. J., Davis, G., Alfsen, C., \& Elmqvist, T. (2010). Urban Transitions: On Urban Resilience and HumanDominated Ecosystems. Ambio, 39(8), 531-545. https://doi.org/10.1007/s13280010-0081-9

Farrelly, M., \& Brown, R. (2011). Rethinking urban water management: Experimentation as a way forward? Global Environmental Change, 21(2), 721-732. https://doi.org/10.1016/j.gloenvcha.2011.01.007

Finewood, M. H. (2016). Green Infrastructure, Grey Epistemologies, and the Urban Political Ecology of Pittsburgh's Water Governance. Antipode, 48(4), 1000-1021. https://doi.org/10.1111/anti.12238

Fisher, J., \& Brown, K. (2009). Wind energy on the Isle of Lewis: implications for deliberative planning. Environment and Planning A, 41(10), 2516-2536. https://doi.org/10.1068/a41129

Fitzgerald, J., \& Laufer, J. (2016). Governing green stormwater infrastructure: the Philadelphia experience. Local Environment, 1-13. https://doi.org/10.1080/13549839.2016.1191063

Forrester, J., Cook, B., Bracken, L., Cinderby, S., \& Donaldson, A. (2015). Combining participatory mapping with Q-methodology to map stakeholder perceptions of complex environmental problems. Applied Geography, 56, 199-208. https://doi.org/10.1016/j.apgeog.2014.11.019

Freitag, A. (2014). Naming, Framing, and Blaming: Exploring Ways of Knowing in the Deceptively Simple Question “What is Water Quality?" Human Ecology, 42(2), 325-337. https://doi.org/10.1007/s10745-014-9649-5

Gartland, L. (2008). Heat Islands: Understanding and Mitigating Heat in Urban Areas. New York, NY: Earthscan.

Glaser, B., \& Strauss, A. (1967). The Discovery of Grounded Theory. London: Weidenfeld and Nicholson.

Guttman, L. (1954). Some necessary conditions for common-factor analysis. Psychometrika, 19(2), 149-161. 
Hayhoe, K., Wuebbles, D., Hellman, J., Lesht, B., \& Nadelhoffer, K. (2007). Chicago Climate Action Plan: Climate Change and Chicago: Projections and Potential Impacts. In Chicago Climate Action Plan.

IPCC. (2014). Climate Change 2014: Synthesis Report. Contribution of Working Groups I, II and III to the Fifth Assessment Report of the Intergovernmental Panel on Climate Change. (R. Pachauri \& Meyer LA, Eds.). Geneva, Switzerland.

Kaiser, H. (1960). The application of electronic computers to factor analysis. Educational and Psychological Measurement, 20, 141-151.

Kaplowitz, M. D., \& Lupi, F. (2012). Stakeholder preferences for best management practices for non-point source pollution and stormwater control. Landscape and Urban Planning, 104(3-4), 364-372. https://doi.org/10.1016/j.landurbplan.2011.11.013

Kirchhoff, C. J., Lemos, M. C., \& Engle, N. L. (2013). What influences climate information use in water management? The role of boundary organizations and governance regimes in Brazil and the U.S. Environmental Science \& Policy, 26, 618.

Malec, S. (2003). Storm Water Management in the City of Chicago. In National Conference on Urban Stormwater: Enhancing Programs at the Local Level (pp. 215-220).

Matthews, T., Lo, A. Y., \& Byrne, J. A. (2015). Reconceptualizing green infrastructure for climate change adaptation: Barriers to adoption and drivers for uptake by spatial planners. Landscape and Urban Planning, 138, 155-163. https://doi.org/10.1016/j.landurbplan.2015.02.010

Newell, J. P., \& Cousins, J. J. (2015). The boundaries of urban metabolism: Towards a political-industrial ecology. Progress in Human Geography, 39(6), 702-728. https://doi.org/10.1177/0309132514558442

NRDC. (2010). Re-Envisioning the Chicago River: Adopting Comprehensive Regional Solutions to the Invasive Species Crisis. Retrieved from www.nrdc.org/water/

Ntelekos, A. a., Oppenheimer, M., Smith, J. a., \& Miller, A. J. (2010). Urbanization, climate change and flood policy in the United States. Climatic Change, 103(3-4), 597-616. https://doi.org/10.1007/s10584-009-9789-6

O’Neill, S. J., Boykoff, M., Niemeyer, S., \& Day, S. a. (2013). On the use of imagery for climate change engagement. Global Environmental Change, 23(2), 413-421. https://doi.org/10.1016/j.gloenvcha.2012.11.006

Pallett, H., \& Chilvers, J. (2014). Organizations in the making: Learning and intervening at the science-policy interface. Progress in Human Geography. https://doi.org/10.1177/0309132513518831

Powers, T. H., \& Emanuel, R. (2014). City of Chicago Stormwater Management Ordinance Manual, (March).

Rittel, H. W. J., \& Webber, M. M. (1973). Dilemmas in a general theory of planning. Policy Sciences, 4(2), 155-169. 
Robbins, P. (2006). The politics of barstool biology: Environmental knowledge and power in greater Northern Yellowstone. Geoforum, 37, 185-199.

Robbins, P., \& Krueger, R. (2000). Beyond bias? The promise and limits of Q method in human geography. Professional Geographer, 52(4), 636-648.

Robertson, M. M. (2004). The neoliberalization of ecosystem services: Wetland mitigation banking and problems in environmental governance. Geoforum, 35(3), 361-373. https://doi.org/10.1016/j.geoforum.2003.06.002

Schäffler, A., \& Swilling, M. (2013). Valuing green infrastructure in an urban environment under pressure - The Johannesburg case. Ecological Economics, 86, 246-257. https://doi.org/10.1016/j.ecolecon.2012.05.008

Setiawan, A. D., \& Cuppen, E. (2013). Stakeholder perspectives on carbon capture and storage in Indonesia. Energy Policy, 61, 1188-1199. https://doi.org/10.1016/j.enpol.2013.06.057

Star, S. L., \& Griesemer, J. R. (1989). Institutional Ecology, 'Translations' and Boundary Objects: Amateurs and Professionals in Berkeley's Museum of Vertebrate Zoology, 1907-39. Social Studies of Science, 19(3), 387-420.

Swedeen, P. (2006). Post-normal science in practice: A Q study of the potential for sustainable forestry in Washington State, USA. Ecological Economics, 57(2), 190208. https://doi.org/10.1016/j.ecolecon.2005.04.003

Ward, L. (2013). Eco-governmentality revisited: Mapping divergent subjectivities among Integrated Water Resource Management experts in Paraguay. Geoforum, 46, 91102. https://doi.org/10.1016/j.geoforum.2012.12.004

Watts, S., \& Stenner, P. (2012). Doing Q Methodological Research: Theory, Method, and Interpretation. London: SAGE Publications.

Webler, T., Danielson, S., \& Tuler, S. (2009). Using Q Method to Reveal Social Perspectives in Environmental Research. Greenfield MA: Social and Environmental Research Institute.

White, S. S., \& Boswell, M. R. (2007). Stormwater Quality and Local Government Innovation. Journal of the American Planning Association, 73(2), 185-193. https://doi.org/10.1080/01944360708976152 
Table 1. Quasi-normal distribution chart

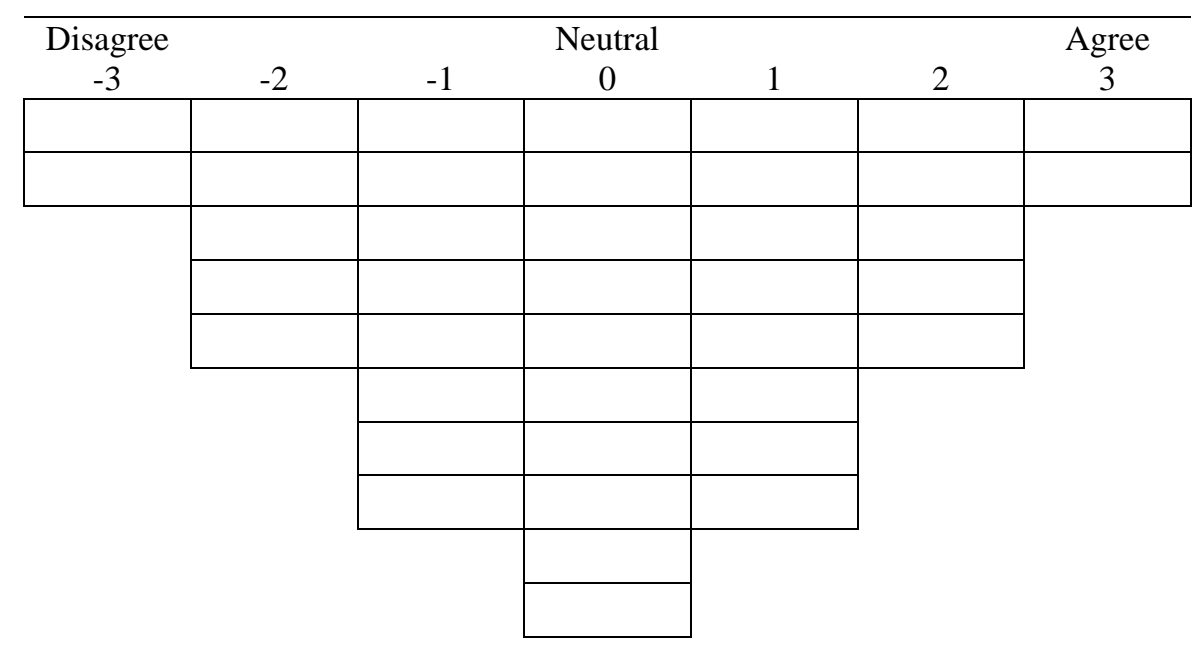


Table 2. Factor Characteristics for Chicago

\begin{tabular}{lll} 
Factor Characteristics & \multicolumn{2}{l}{ Factor } \\
\cline { 2 - 3 } & 1 & 2 \\
\cline { 2 - 3 } Eigenvalue & 3.221 & 2.654 \\
No. of defining variables & 7 & 6 \\
Composite reliability & 0.966 & 0.96 \\
SE of factor scores & 0.186 & 0.2 \\
\% total variance & 23.01 & 18.962
\end{tabular}


Table 1. Infrastructural Interventionist distinguishing statements

Group One: Infrastructural Interventionist

Statement (significant at $\mathrm{p}>0.05$ )

3. We lack the data needed for the adoption green infrastructure and to accurately quantify its performance.

4. The trouble within the city is that we're so congested and built up we don't have the space for many types of green infrastructure; space is a significant limitation.

7. I think there is a cultural problem. Stormwater engineers see only engineering solutions and green infrastructure is not part of that.

9. We need stricter laws and regulations to address stormwater because change is not going to happen voluntarily.

11. Science and data should direct decisions on stormwater and infrastructure. We need data driven and fact-based approaches drawing on the best available science and engineering.

14. Stormwater management needs economic instruments to put a value on stormwater and make it a resource rather than a hazard.

15. Corporations and private interests should have the chance to develop their own targets for stormwater abatement.

16. A mitigation bank for stormwater will help foster public-private partnerships to address stormwater by allowing developers to meet LID requirements by paying into that bank.

21. We need stormwater fees. Municipalities need fees and cost sharing plans.

22. Stormwater fees are not feasible, nor are they enough for successful implementation in the long term. Stormwater fees are problematic.

28. Big systems and dams or reservoirs are important for floods and stormwater mitigation, but after the rain, how you handle that water is important for water quality and/or supply.

29 Centralized urban water systems are maladapted to address climate change impacts and environmental stressors.

32. Resilience of urban water systems will be improved by moving away from the centralized model and using more distributed solutions like green infrastructure.

34. As we build green infrastructure we are going to change the nature of neighborhoods. We are going to push working class people out as we build more economic development around green space. 
Table 4. Institutional Interventionist distinguishing statements.

Group Two: Institutional Interventionist

Statement (significant at $\mathrm{p}>0.05$ )

1. One of our biggest barriers is increased regulation.

4. The trouble within the city is that we're so congested and built up we don't have the space for many types of green infrastructure; space is a significant limitation.

11. Science and data should direct decisions on stormwater and infrastructure. We need data driven and fact-based approaches drawing on the best available science and engineering.

14. Stormwater management needs economic instruments to put a value on stormwater and make it a resource rather than a hazard.

20. An integrated management approach is critical. There needs to be a shift towards more integrated approaches across all of the institutions and sectors concerned with the management of water.

30. Larger centralized projects for handling and capturing stormwater are typically more cost-efficient than trying to treat it at thousands of small sources. Centralized stormwater projects make more financial sense than distributed and decentralized stormwater projects.

32. Resilience of urban water systems will be improved by moving away from the centralized model and using more distributed solutions like green infrastructure.

33. Distributed projects are not effective; they don't scale up across the city or to other sites and will never meet the level of stormwater abatement and/or capture needed.

35. For every dollar we spend on a water quality project that's one less emergency service dollar, recreation dollar, or funds for other services. It's hard to justify money for stormwater management.

37. I think there definitely will be a need for new institutions and rules to manage stormwater.

40. Rather than focusing on new development, we need to focus on the existing development and encourage retrofitting. Only looking at new developments hurts us. 
Appendix A. shows and compares the idealized sort for the Infrastructural Interventionist and the Institutional Interventionist.

\begin{tabular}{|c|c|c|c|}
\hline \multicolumn{2}{|c|}{ Statement } & \multicolumn{2}{|c|}{ Factor } \\
\hline & 1 & 2 \\
\hline 1. & One of our biggest barriers is increased regulation. & -2 & $\underline{-2}$ \\
\hline 2. & $\begin{array}{l}\text { Implementation is a barrier in large part due to NIMBY type of concerns. People do not want to } \\
\text { be liable. }\end{array}$ & -1 & $\overline{0}$ \\
\hline 3. & $\begin{array}{l}\text { We lack the data needed for the adoption green infrastructure and to accurately quantify its } \\
\text { performance. }\end{array}$ & $\underline{-2}$ & -1 \\
\hline 4. & $\begin{array}{l}\text { The trouble within the city is that we're so congested and built up we don't have the space for } \\
\text { many types of green infrastructure; space is a significant limitation. }\end{array}$ & $\underline{-1}$ & $\underline{1}$ \\
\hline 5. & $\begin{array}{l}\text { Climate uncertainty is the most difficult challenge for proactive adaptation planning for } \\
\text { stormwater management. }\end{array}$ & -1 & 0 \\
\hline 6. & Land-use change presents the most difficult challenge to stormwater management. & -1 & 0 \\
\hline 7. & $\begin{array}{l}\text { I think there is a cultural problem. Stormwater engineers see only engineering solutions and } \\
\text { green infrastructure is not part of that. }\end{array}$ & $\underline{1}$ & -1 \\
\hline 8. & $\begin{array}{l}\text { Getting people to apply to incentive programs is problematic because people don't care about } \\
\text { stormwater management and lack knowledge of water issues. }\end{array}$ & 1 & 0 \\
\hline & $\begin{array}{l}\text { We need stricter laws and regulations to address stormwater because change is not going to } \\
\text { happen voluntarily. }\end{array}$ & $\underline{\mathbf{3}}$ & 0 \\
\hline 10. & $\begin{array}{l}\text { Failure to address stormwater, like climate change, is a fault of political leaders; they are the } \\
\text { ones who need to be educated and incentivized to innovate. }\end{array}$ & 1 & 1 \\
\hline 11. & $\begin{array}{l}\text { Science and data should direct decisions on stormwater and infrastructure. We need data driven } \\
\text { and fact-based approaches drawing on the best available science and engineering. }\end{array}$ & $\underline{\mathbf{3}}$ & $\underline{\mathbf{2}}$ \\
\hline 12. & $\begin{array}{l}\text { Development of a tradable credit system, with appropriate regulatory safeguards, will encourage } \\
\text { investment in green infrastructure and help deliver stormwater mitigation at the lowest possible } \\
\text { cost. }\end{array}$ & 1 & 1 \\
\hline 13. & $\begin{array}{l}\text { We need market based approaches and fewer government interventions and regulations to } \\
\text { finance stormwater management. }\end{array}$ & -2 & -1 \\
\hline 14. & $\begin{array}{l}\text { Stormwater management needs economic instruments to put a value on stormwater and make it a } \\
\text { resource rather than a hazard. }\end{array}$ & $\underline{\mathbf{2}}$ & $\underline{\mathbf{3}}$ \\
\hline 15. & $\begin{array}{l}\text { Corporations and private interests should have the chance to develop their own targets for } \\
\text { stormwater abatement. }\end{array}$ & $\underline{-3}$ & 0 \\
\hline 16. & $\begin{array}{l}\text { A mitigation bank for stormwater will help foster public-private partnerships to address } \\
\text { stormwater by allowing developers to meet LID requirements by paying into that bank. }\end{array}$ & $\underline{\mathbf{2}}$ & 0 \\
\hline 17. & $\begin{array}{l}\text { Stormwater, or water more generally, should not be guided by market, economic, or financial } \\
\text { principles. }\end{array}$ & -1 & -1 \\
\hline 18. & $\begin{array}{l}\text { Waste water, water supply, flood water, water quality and all of that stuff is just water. If you } \\
\text { just think of it as one water then you can manage it much more efficiently. }\end{array}$ & 0 & 0 \\
\hline 19. & $\begin{array}{l}\text { We don't need more integrated approaches. We need better enforcement of existing regulations } \\
\text { and improvement of local codes and ordinances; integrated water resource planning is not the } \\
\text { answer }\end{array}$ & -1 & -3 \\
\hline 20. & $\begin{array}{l}\text { An integrated management approach is critical. There needs to be a shift towards more } \\
\text { integrated approaches across all of the institutions and sectors concerned with the management } \\
\text { of water. }\end{array}$ & 2 & $\underline{\mathbf{3}}$ \\
\hline 21. & We need stormwater fees. Municipalities need fees and cost sharing plans. & $\underline{\mathbf{2}}$ & 1 \\
\hline 22. & $\begin{array}{l}\text { Stormwater fees are not feasible, nor are they enough for successful implementation in the long } \\
\text { term. Stormwater fees are problematic. }\end{array}$ & $\underline{-2}$ & -2 \\
\hline 23. & $\begin{array}{l}\text { Stormwater needs to be held and used on-site; there are too many concerns about unregulated } \\
\text { off-site mitigation. }\end{array}$ & 1 & 0 \\
\hline 24. & $\begin{array}{l}\text { Stormwater mitigation should be able to occur off-site; it offers more flexible opportunities. Off- } \\
\text { site approaches lead to better outcomes than on-site. }\end{array}$ & 0 & -1 \\
\hline & $\begin{array}{l}\text { We need to maintain the narrative of engagement by redefining city services and bringing the } \\
\text { expertise to the neighborhoods. We need a grass roots community driven approach to create }\end{array}$ & 1 & 2 \\
\hline
\end{tabular}


better outcomes.

26. Homeowners need to be educated and they need to educate each other about the benefits of improved stormwater management. They need to be the targets of interventions because community driven approaches tend to be more effective than data driven approaches.

27. Local residents' contributions to decision-making usually show a lack of expertise, are not factual, or biased.

28. Big systems and dams or reservoirs are important for floods and stormwater mitigation, but after the rain, how you handle that water is important for water quality and/or supply.

29 Centralized urban water systems are maladapted to address climate change impacts and environmental stressors.

30. Larger centralized projects for handling and capturing stormwater are typically more costefficient than trying to treat it at thousands of small sources. Centralized stormwater projects make more financial sense than distributed and decentralized stormwater projects.

31. LID offers economic benefits, such as deferring or even replacing costly large grey stormwater infrastructure projects. LID is more cost effective than grey infrastructure.

32. Resilience of urban water systems will be improved by moving away from the centralized model and using more distributed solutions like green infrastructure.

33. Distributed projects are not effective; they don't scale up across the city or to other sites and will never meet the level of stormwater abatement and/or capture needed.

34. As we build green infrastructure we are going to change the nature of neighborhoods. We are going to push working class people out as we build more economic development around green space.

35. For every dollar we spend on a water quality project that's one less emergency service dollar, recreation dollar, or funds for other services. It's hard to justify money for stormwater management.

36. I'm really opposed to creating new institutions or rules to manage stormwater. There are too many agencies and there is too much diversity already.

37. I think there definitely will be a need for new institutions and rules to manage stormwater.

38. With many community groups and NGOs there are issues with them maintaining the infrastructure or with them focusing too narrowly on certain issues.

39. I think there is enough NGO capacity within the city to have a better-coordinated and strategic approach to green infrastructure.

40. Rather than focusing on new development, we need to focus on the existing development and encourage retrofitting. Only looking at new developments hurts us. 